Journal of English Language Teaching and Applied Linguistics

ISSN: 2707-756X

DOI: $10.32996 /$ jeltal

Journal Hompage: www.al-kindipublisher.com/index.php/jeltal

\title{
Role of Short Stories in EFL Classes
}

Chiossa Luís

${ }^{1}$ Lecturer, UniRovuma University at Department of Social Sciences and Art, Lichinga, Mozambique.

Corresponding Author: Chiossa Luís, E-mail: chiossaluis@gmail.com

ARTICLE INFORMATION ABSTRACT

Received: November 13, 2020

Accepted: December 15, 2020

Volume: 2

Issue: 5

DOI: $10.32996 /$ jeltal.2020.2.5.2

\section{KEYWORDS}

Role, linguistic skills, EFL, short stories, teachers
The research seeks to investigate why most teachers at Cristiano Paulo Secondary School are not using short stories in English Language Teaching despite the fact that they know the importance of short stories, and suggest techniques to increase the use of short stories in ELT (English Language Teaching). The study will take place in Niassa Province, specifically at Cristiano Paulo Taimo Secondary School - Lichinga. The sample of this study will be students and teachers of English of grade 12 of the school aforementioned and will be determined through simple random sampling, mixed approach will be the approach in use for this study and data for this study will be collected through questionnaires and observation. 2 teachers of English and 10 students of grade 12 participated in the survey study. The data will be analyzed through statistics and themes. Searching for practical ways to improve students' English language skills is a real concern for all English teachers. There is a consensus among English Language Teaching practitioners regarding the significance of reading for learning new languages, since reading gives depth to language learning (Stern, 2001). Therefore, teachers are obligated to provide their students with interesting and suitable texts to read. Real stories are by far more interesting and involving than scientific and historical texts. Thus, the researcher expects that this study will help teachers to improve the teaching of English Language through short stories and students will be able to develop speaking skills.

\section{Introduction}

The research project proposal entitled "The Role of Short Stories in EFL (English as Foreign Language) Class" will be carried out at Cristiano Paulo Taimo Secondary School with grade 12 teachers and students. The study seeks to investigate the study seeks to investigate what most teachers make of the role of short stories in EFL especially with grade 12 students at CPT (Cristiano Paulo Taimo). Cristiano Paulo Taimo Secondary School is the public school located in the outskirts of Lichinga town. It is situated between the two villages called Nomba and Matola and it is four kilometers away from Lichinga town.

\subsection{Statement of the problem}

During teaching practices, the researcher noticed that most teachers did not use short stories in their English Language Classes. The researcher felt that the tendency in the English Language classes was to practice language skills (reading, speaking, writing and listening) around topics (texts from grade 12) related to sports, business, environment, entertainment, technology, diseases, politics, arts and other topics different from short stories. Then, teachers were more dependent on the students' course book than to bring their own materials into their classes. Although Grade 12 (twelve) students' textbooks brought literature in unit 9 (Inglês 12a classe /2011), teachers at this level did not use short stories as additional materials because grade 12 textbooks have just explored literary terminology, figures of speech in isolation such as metaphor, personification, similes and the like other than short stories.

K C AL-KINDI CENTER R D FOR RESEARCH Your gatewoy to world-class resecrch
Published by Al-KindiCenter for Research and Development. Copyright (c) the author(s). This is an open access article under CC BY license (https://creativecommons.org/licenses/by/4.0/) 
Most teachers overtly showed clear dependence on course book texts. In addition, teachers did not give time themselves to exploit materials that can develop all English language skills (reading, writing, speaking and listening) as a result, the process of teaching and learning has been based on form-focused instruction only. In this context, therefore, the researcher identified the problem. Thus, this study has the following research question: What is the teachers' perception on the role of short stories in the EFL classes?

\subsection{Critical questions}

a. Are the teachers aware of using short stories in their English classes at CPT Secondary School?

b. What are the potential benefits of using short stories in English Language class?

c. What can be done to make teachers of English at CPT explore short stories in English classes?

\subsection{Hypotheses}

In the present study, the researcher used directional hypotheses because the researcher made a prediction of the possible outcome of the research. Thus, hypothesis, for most researchers, is an anticipated answer to the problem, or a suggested answer to the problem.

a. Teachers may not use short stories in an English class because they do not know their importance in English language Teaching;

b. Teachers may not use short stories in their lessons because teachers do not know how to use them in English Language Class;

c. Teachers may not use short stories because of poor teaching and learning resources.

\subsection{Objectives}

There is one general objective and three specific objectives presented in this research and these are as they follow:

\subsubsection{General objective}

a. The purpose of this study is to find out the role of short stories in learning the EFL at Cristiano Paulo Secondary school at Cristiano Paulo Taimo Secondary School.

\subsubsection{Specific objectives}

a. To analyze teachers' perceptions of employing short stories in English classes at CPT Secondary School.

b. To describe the benefits of using short stories in English language Teaching;

c. To suggest activities to help teachers explore short stories in their English lessons.

\subsection{Delimitation of the study}

In this research, the researcher limits the problem of the use of short stories as extra - materials in practicing language skills (reading, listening, speaking and writing) with grade 12 students from Cristiano Paulo Secondary School. Furthermore, since integrating short stories in English Language Teaching provide a real model of language use, the scope of this study is the use of literary texts, especially short stories, as authentic materials that offer various benefits in foreign language teaching programs.

\subsection{Significance of the study}

The teaching of English in Mozambique aims at enabling students to communicate in English, thus the approach adopted is communicative language teaching. The main focus is to make learners to understand the intention and expression of the writers and speakers. Communicative functions are more important rather than linguistic structures.

Maciel (1986 cited in Mckay, 1986) argues that literature provides an ideal basis for integrating the development of four language skills, that is, listening, speaking, reading, and writing.

Thus, the significance of this research is as it follows:

1. For the students: the first is to help students cope with difficulties in vocabulary learning by using of English short stories, and developing the students' achievement in their language abilities (reading, listening, writing and speaking). The second is to motivate and encourage the students to speak English in front of the class and be able to use of English with foreign people. 
2. For the researcher: the researcher can provide experience about research that related to the role of short stories as materials in the EFL.

3. For the teachers: the existence of this research aims to solve the problems that may arise during the teaching process. Furthermore, this research can be used as references to make learning process enjoyable and motivating especially in using short stories in their lessons. Similarly, from what has been said above, searching for practical ways to improve students' English Language skills is a real concern for all English teachers.

In addition, it is important to carry out this research because the researcher wants to find out why do most teachers do not use short stories in English Class at Cristiano Paulo Taimo Secondary School since short stories may provide an interesting and thought-provoking point of comparison. Short stories are more beneficial than informational material in stimulating the acquisition process as they provide authentic contexts for processing new language.

However, if students are not exposed to extra materials such as short stories, students will unlikely familiarize themselves with different language uses, forms or conventions as a result language will be difficult to develop. On the other hand, students may not feel developing a very important ability for reading, which is, predicting skills. In addition, the findings of this study will be of highly valuable for teachers as well as for students. As professionals, teachers will improve their teaching skills. For the students, it will be helpful in the sense that short stories will enhance their motivation and interest in learning English language. Short stories have been motivating materials that reinforce English Language acquisition.

\section{Literature Review}

Within the field of language teaching there is a plenty of knowledge that has been gathered by different authors or scholars who are stated talking about the same topic: the use of short stories in ELT (English Language Teaching). In this chapter, the researcher presents different aspects dealing with the knowledge discussed by different authors related to the effectiveness of using short stories in the English Language class. The researcher brings the main concepts of some literary genres and their usability in English Classes.

\subsection{Concepts}

In this section the researcher aims to define some literary genres and to show the methodological assumptions about the aim of literature in the classroom and define language skills (reading, listening, speaking and writing).

Lazar cited in Murdoch (1978, p.123) defines literature to be "a sort of disciplined technique for arousing certain emotions". Taking into account this definition, it is said that literature is "feelings" and "thoughts" in black and white". Furthermore, Lazar (1993, p.3) goes on saying that, "literature is the question minus the answer".

With regard to the aim of using literature in ELT, teachers of grade 12 at Cristiano Paulo Taimo do not expect to reach any definitive interpretation of a literary text with their students but rather they should use the text as the basis for generating discussion, controversy and critical thinking in the classroom.

In addition to the concepts of literature, the researcher's point of view is that literature is the use of language to evoke a personal response in the reader or listener. Then, literature is written material such as novel, romance, myth, legend, fable, parables, etc. Thus, literature is the use of language to evoke a personal response in the reader or listener.

Concerning to this definition, most teachers of grade 12 at Cristiano Paulo Taimo did not use literature as a way of motivating their students. However, among literary genres short stories seem to be the most appropriate to use in an English class.

Lazar (1993, p.73) said that, "a short story is about people who do not really exist and it is a work of fiction, so it involves the imagination".

In the researcher's point of view, in fact, short story is a short fictional story. A typical story involves chronology, or a sequence of events, and causation, that is, events are somehow connected with each other.

Brumfit \& Carter (1986, p.76) define genres as "a kind of literary or artistic work and include romance, novel, poetry and short stories". 
Short story has a plot, and characters who are somehow connected with each other. Then, teachers of grade 12 at Cristiano Paulo Taimo may select short stories that they know well and it has to be presented in a chronology of events clearly sequenced. For instance, folktales are usually presented in a chronological order. This can be demonstrated with a short story (fable).

Lazar (1993, p. 89), "novels and short stories share a great many features in common."

Indeed, novel is likely to be a larger cast of characters than in a short story, the plot may be more complicated and methods of narration can sometimes be more complex to the learners. Like the short story, the traditional novel involves a chronological sequence of events, linked by relations of cause and effect. Whereas novel is a long fictional story in book form (Abrams, 1970)

Therefore, most teachers of grade 12 at Cristiano Paulo Taimo are hardly familiar with novels because its description of events in a novel is shaped by a narrator, and the language of the novel is used in highly self-conscious way to convey particular effects. Teachers of grade 12 at Cristiano Paulo Taimo do not cope with the length of the novel and the amount of time teachers can spend in class reading the novel depends on the syllabus. Generally, it is best to choose a short story.

Bretz (1990, p.4) defines a myth as "a traditional story that explains the beliefs of a people about the natural and human world. The main characters in myths are usually gods or supernatural heroes." These stories are set in the distant past. The people who told these stories believed that they were true.

Therefore, by learning other's beliefs, students become more aware of their own culture. Traditional story can help students to learn universal values such as justice, honesty, humanity, religiosity and social, moral, and spiritual values.

Abrams (1970, p. 5) considers a legend as "a traditional story about the past. The main characters are usually kings or heroes."

A fable as it defined by Mckay (1986, p.56), "it is a brief story intended to teach a moral lesson. The main characters are usually animals, objects in nature (e.g. mountains, lakes, stones) or forces of nature (e.g. the sun, the wind, the rain), which are given human qualities".

Students of grade 12 at Cristiano Paulo Taimo secondary school favorably showed positive attitudes towards fables. So, teachers can take advantage of using fables in the classroom and they may find that events in fables are usually presented in a chronological order. In this perspective, the researcher thinks that the best simple way of introducing literary elements is using fables in ELT because fables overtly display theme, message, characters (usually animals, objects, mountains, rivers, etc.), setting, plot and metaphorical language.

In addition, using fables in the class can educate students by providing them moral values that most schools national wide lack.

Unlikely, "A parable is a brief story that illustrates a moral principle through the use of metaphor. The main characters of parables are human beings." (Littlewood, 2000, p. 17)

There is a locally written English textbook that has been produced, entitled "English for Mozambique" in which there are some fables such as "the Lizard and the frog", "The hyena who burst" and others. The authors of the book are Mozambicans (Mkuti \& Mpiuka 1987, pp.43-44).

Each one of the definitions above has certain implications for the approach teachers adopt to using literature in language classroom.

\subsection{Methodological assumptions}

Collins Paperback English Dictionary "Assumption is something that is taken for granted." It can also be understood as unquestioning acceptance that something is true. 
"Granted a" means to accept that something is true without requiring proof.

It is said that studying the language of the literary text will help to integrate the language and literature syllabuses more closely.

Sell (1995, p. 4) affirms that "detailed analysis of the language of the literary text will help students to make meaningful interpretations or informed evaluations of it."

At the same time, students will increase their general awareness and understanding of English. Students are encouraged to draw on their knowledge of familiar grammatical, lexical or discourse categories to make aesthetic judgments of the text.

So, this approach may provide useful exposure to, or revision of, grammar and vocabulary in interesting new contexts. It is a way of justifying the inclusion of short stories in the language syllabus since it fulfils students' main aim, that is, to improve their knowledge of the language.

Material is chosen on the basis of whether it is appropriate to students' interests and will stimulate a high level of personal involvement. Material is often organized thematically, and may be placed alongside non-literary materials which deal with a similar theme.

(Lazar, 1993) material is chosen for the way it illustrates certain stylistic features of the language but also for its literary merit.

\subsection{Reading}

Shanahan (1997, p.6) defines reading as "a complex cognitive process of decoding symbols in order to construct or derive meaning (reading comprehension). Reading is a means of language acquisition, of communication, and of sharing information and ideas".

In addition, like all languages, reading is a complex interaction between the text and the reader which is shaped by the reader's prior knowledge, experiences, attitude, and language community which is culturally and socially situated. The reading process requires continuous practice, development, and refinement.

On the other hand, reading requires creativity and critical analysis. Readers integrate the words they have read into their existing framework of knowledge or schema (schemata theory). So, reading is the act of looking at script and signs and recognizes them. It is said that reading is a skill of the elite because one has to go to any training in order to read.

\subsection{Listening}

Listening is a conscious activity or something that interest he/she when he/she is hearing. Then, listening entails: hearing the sounds, familiarity with the topic, intonation and stress, coping with redundancy and noise, capacity to repeat what comes next, understanding colloquial vocabulary, understanding different accents, fatigue, predicting. If students are listening to something entertaining, then they are likely to attend and get full benefit from the listening experience.

Ur (1984, p.63) emphasizes that "stories there are, in short, to suit every taste and every level of proficiency."

Short story can also be a powerful and motivating source for teaching both speaking and listening. Oral reading, dramatization, improvisation, role playing and discussion are some effective learning activities which center on a short story EFL classes can use for enhancing speaking and listening.

\subsection{Speaking}

Speaking has to do with uttering words, intonation, and spontaneous expression, use of interjections, gestures and facial expressions. Thus, speaking has to do with being able to use sound system in order to speak.

Lightbown \& Spada (1993, p.119) classify speaking skills into "linguistic competence, which has to do with correct pronunciation (stress, intonation), correct use of grammatical structures; and communicative competence, that is, the ability to use language in a variety of settings or simply, the ability to convey messages in spite of a lack of grammatical accuracy." 
In addition, students are exposed to authentic material, that is, in the context of this research, authentic material is language where no concessions are made to foreign speakers. It is normal, natural language used by native or competent speakers of a language. This is what students encounter in real life if they come into contact with target-language speakers, and, precisely because it is authentic, it is unlikely to be simplified or spoken slowly.

\subsection{Writing}

Writing is a representation of sounds into graphemes. People think before writing. Then, writing involves ordering ideas, grammar rules, and knowledge of alphabet, having a range of vocabulary, punctuation, accurate spelling and sentence structure. Short stories can be used to teach language skills. Thus, language skills can be classified into productive (writing and speaking) and receptive skills (reading and listening).

\subsection{Historical background of the inclusion of literature in the English classroom}

In the nineteenth century, the Grammar Translation Method (GTM) predominated English as Second Language Teaching/English as Foreign Language Teaching. During the era, translating literary texts from the second/foreign language to the students' native language was one of the main learning activities.

Therefore, "literary works were a notable source of material in ESL/EFL teaching", (Prodromou, 2000, p.7).

But when GTM was replaced by the structuralism Approach in 1960s to the end of 1970s, literature was no longer used. Structuralism was concerned with correctness of grammatical form and not with content or interpretation of the written word or style.

In other words, teaching a foreign language was regarded as a matter of linguistics. Then, when Direct Method, The Audio lingual method, Community Language Learning, Suggestopedia, the Silent Way, Total Physical Response, and the Natural Approach successively dominated ESL/EFL teaching, literature was not utilized. Later on and with the appearance of the Communicative Approach in the late $70^{\prime}$ s and very early $80^{\prime}$ s, literature was also ignored. The tendency in EFL classrooms was to teach "usable, practical" contents. Thus, literary works had no place in the curriculum. During this period most EFL courses were mainly aimed to enable the students to communicate orally. Consequently, dialogues dominated the curriculum.

However, since the 1980s the situation changed quite radically when literature found its way back into the teaching of EFL. But, different from the way it was used with the GTM, the current use of literary works in ESL/EFL classes is to improve communicative competence and provide "a springboard for the development of critical thinking and aesthetic students' awareness on the culture and society of the relevant country."

\subsection{Benefits of using short stories in ELT}

Theoretically, using literature in Language Teaching is very advantageous because it offers 4 (four) benefits: authentic material, cultural enrichment, language advancement, and personal growth (Collie \& Slater, 1991, p.10). This is in line with Lazar (1993) who notes four benefits of using short stories to teach ESL/EFL, i.e. motivational, literary, cultural and higherorder thinking benefits.

First of all, literary texts can be more beneficial than informational material in stimulating the acquisition process as they provide authentic contexts for processing new language.

Literary texts expose learners to fresh themes and unexpected language. In this sense, a literary text is an authentic text, real language in context, to which we can respond directly (Brumfit and Carter, 1986, p.15).

This quality appears to make literature suitable and valuable to language teaching in many contexts and cultures. In addition, since literary texts contain language intended for native speakers, literature stands as a model for language learners to become familiar with different forms and conventions.

Second, containing real examples of grammatical structures and vocabulary items, the literary texts raise learners' awareness of the range of the target language and advance their competence in all language skills (Povey, 1967). 
Literary texts are not written for the specific purpose of teaching. Instead, they deal with "things which mattered to the author when he wrote them" (Marley, 1989, p.12).

So, compared to the language samples in the textbooks, the language is far richer and more varied. Many genuine features of the written language such as "the formation and function of sentences, the variety of possible structures, and the different ways of connecting ideas are presented at many levels of difficulty" (Collie \& Slater, 1994, p.5).

According to Widdowson (1975, cited in Lazar 1993, p. 18) "by assigning learners to explore the literary language, they have been at the same level encouraged to think about the norms of the language use."

Learners are encouraged to familiarize themselves with different language uses, forms or conventions. Such exposure is essential for the learners especially for their language development. Thus, using literature in language teaching has the advantage of providing cultural information about the target language.

Literary texts increase foreign language learners' insight into the country and the people whose language is being learnt (Collie \& Slater, 1991).

Short stories foster learners' ability to interpret discourse in different social and cultural target language contexts (Savvidou, 2004). By reading literary works, learners learn to see a world through another's eyes, observing human values and a different kind of living, and discovering that others' live in very different societies. They will understand and become broadly aware of the social, political, historical, cultural events happening in a certain society.

Finally, "since literature enables students to understand and appreciate other cultures, societies and ideologies different from their own, it encourages personal growth and intellectual development." (Carter \& Long, 1991, pp. 2- 4)

In fact, learners can deepen their cultural understanding through literature.

In accordance with these ideas, Littlewood (2000, p.179) emphasizes the importance of the use of literature in EFL classes by arguing that:

A major problem of language teaching in the classroom is the creation of an authentic situation for language. All language classrooms, especially those outside the community of native speakers, are isolated from the context of events and situations which produce natural language. Literature can overcome this problem because, in literary works, language creates its own context. The actual situation of the reader becomes immaterial as he/she looks on the events created by language. These events create, in turn, a context of situation for the language of the book and enable it to transcend the artificial classroom situation.

Based on these ideas, it is obvious that literary works undoubtedly enable students to understand the language better by providing them with real world experiences, relationships between society and people where the target language is spoken, even if they are fictions.

It is obvious that among literary forms, the short story, as it is defined by Poe (as cited in Abrams, 1970, p. 158) "as a narrative that can be read at one sitting of from one-half hour to two hours, and that is limited to "a certain unique or single effect", to which every detail is subordinate".

Furthermore, in connection to this definition, a short story tells of one event in a very concentrated manner.

In addition, short story seems to be the most suitable one to use in secondary schools.

In regard to the idea that, short story is the most suitable literary genre to use in English Teaching due to its shortness.

Smith (2002, p. 3) listed four advantages of using short stories for language teachers. "First, short stories are practical as their length is long enough to cover entirely in one or two class sessions. 
Second, short stories are not complicated for students to work with their own.

Third, short stories have a variety of choice for different interests and tastes.

Finally, short stories can be used with all levels (beginner to advance), all ages (young learners to adults) and all classes (morning, afternoon, or evening classes)."

Lao \& Krashen (1989, p. 14) showed that "the group reading literary texts indicated improvement in vocabulary and reading skill."

Therefore, short stories can be used for: language practice, reading comprehension and aesthetic appreciation from the beginning and intermediate level. Short stories reinforce language skills, develop motivation or curiosity of the students, and introduce literary elements (theme, message, characters, setting, plot, metaphorical language, culture and values). By learning about the culture, students learn about the past and present, and about people's customs and traditions, short stories develop high-order thinking skills, that is, short stories lead the students to think more critically and students learn from the beginning that critical thinking is more natural, familiar, and even fun.

\subsection{Disadvantages}

Despite the benefits of short stories for students, some objections are always raised against the use of short stories in public secondary schools due to overcrowded classes, overloaded syllabus and limited time - some problems commonly met in elementary to high public schools in almost all developing countries.

First, the deviated and figurative language of poetry necessitates a very long time to grasp. Second, the length of a novel will make it difficult to act out a play in crowded classes within limited course hours.

Short stories may demand a personal response from students without providing sufficient guidance in coping with the linguistic intricacies of the story. Some short stories may be so remote from the students' own experience that they are unable to respond meaningfully to them. Alternatively, some groups of students may dislike having to discuss personal feelings or reactions. If the analysis of short story is undertaken in purely linguistic terms with little chance for personal interpretation, this approach could be very mechanical and de- motivating.

\subsection{Criteria for selecting short stories (text)}

The use of short story in English teaching should be aimed to encourage the students to use what they have previously learnt. By doing this, the learning process will be student-centered. However, the teacher plays a great role. She/he must choose a suitable text to use in class, and should help her/his students understand the story with various activities.

In using short stories to teach English, story selection is indeed one of the most important roles of the teacher. Since the lengths of short stories quite vary, choose a story short enough to handle within course hours. The shortness of the text is important for the students on account of they will see that they can read, understand and finish something in English, and it will give the students a feeling of achievement and self-confidence.

Besides the length of the text, Hill (1994, p.15) points out three other basic criteria for choosing the text: 1) "the needs and abilities of the students; 2 ) the linguistic and stylistic level of the text; 3 ) the amount of background information required for a true appreciation of the material."

The importance of considering these criteria could be perceived by realizing that the vocabulary and sentence structure of the short-story to be studied must be suitable to the level of the students.

The researcher can safely say that the students' cultural background, the students' linguistic proficiency and the students' literary background are the main criteria for selecting texts. Mckay $(1986$, p. 322) and Rivers (1981, p. 230) point out that "students read and enjoy a text if the subject-matter of the text is relevant to their life experience and interests."

The researcher can finally say that it is important to select a story that is at the "instructional level" for the majority of students in the class. 
According to Liddicoat \& Crozet (2000, p. 67), "an instructional level text is one in which a student is able to read at least $90 \%$ of the words accurately and understand no less than $75 \%$ the overall context."

If the text is too difficult, the teacher will spend too much time explaining vocabulary and scaffolding student learning. Students will spend too much time focusing on word recognition and will struggle to understand the meaning.

\subsection{Brief origin of the short story}

In this section, the researcher gives a brief origin of the short story.

Short stories are an important part of every culture. Short stories have their roots in folklore, or the oral tradition of storytelling. In the oral tradition, stories were told to explain beliefs about the world (myths). To remember the great deeds of past kings and Heroes (e.g. legends), to teach moral principles (e.g. fables and parables) or simply for the sake of entertainment (e.g. folktales and fairy tales)

\section{Research Design and Methodology}

This section of work is concerned with the methodology to be used for this study. It entails the research design, the population of study, the sample and sampling technique, the instrumentation and the methods of data analysis.

\subsection{Research Design}

The present study will follow a blending qualitative and quantitative approach, which according to Creswell et al (2003, p. 46) enables us "to gather qualitative input to explain and extend quantitative results, in order to gain a comprehensive insight of the research."

The nature of this research is exploratory, as it explores students and teachers' perceptions of using short stories in English Classes and its potential benefits. Since this is a classroom action research study, the participants are all the teachers and grade 12 students of English at Cristiano Paulo Taimo Secondary School.

\subsection{Instruments and methods of data collection}

The researcher will use a mixed methodology or triangulation which was defined by Povey $(1967$, p.58) as "the combination of methodologies in the study of the same phenomenon." Quantitative and qualitative methods complement each other, which may increase the reliability of the study. The qualitative method can also provide a sequential explanation of the quantitative findings.

The main source of data is a survey questionnaire composed of closed-ended items and open-ended questions. The questions will be categorized into two main themes: students and teachers' perceptions of the use of short - story classes and the linguistic benefits gained from reading short stories. The qualitative method to be used in this study is participant observation: the researcher will observe the teachers during the story classes and analyze the ways of using short stories in the classes.

\subsection{Data Analysis}

Data analysis will be conducted after the researcher gets all data. The data will be gathered from the questionnaire for students (QS), questionnaire for teachers (QT), documents, and observation. In this case study research, the researcher will analyze data based on interactive model of analysis by Miles and Huberman (1984). These models consist of data reduction, data display and conclusion drawing or verification.

\subsubsection{The data reduction}

Data reduction is obtained from observation and it is complex and complicated. Therefore, the researcher will need to analyze by data reduction. Data reduction in this case study research will be done through the process of selecting the important data, focus on important aspect, finding the theme and pattern, discard unnecessary aspects, simplifying, abstracting, and transforming the data that emerge in written-up field notes. In this stage, the result of observation will be turned into document analysis. In addition, data that will have been reduced will provide an illustration more clearly and make the researcher easy to do future research. In this case study research, the researcher will reduce the data and focusing on the teachers' activity and learning situation in the classroom. 


\subsubsection{The data display}

Display as an organized, compressed assembly of information that allows conclusion drawing. Based on Miles and Huberman (1984) defines that the qualitative data most frequent form of display is in the past of narrative text. The data display is used to understanding of phenomenon easily and make a planning or structure of case study for conducting future research. In this case study, the researcher will use brief notes and narrative text to display data.

\subsubsection{The conclusion Drawing / Verification}

The next stage is drawing conclusion or verification. Form the very beginning conclusion is temporary; there are two possibilities upon temporary conclusion whether it will change if the researcher does not find strong evidence that will have been supported by the next data collection. But, if the conclusion in the beginning will be supported by valid evidence and consistence, it means that the conclusion is credible.

\section{Results and Discussion}

At this stage, the researcher presented the research findings in reflection of hypotheses prior presented for the purpose of predicting the possible outcomes of the study or evaluating their reliability and validity.

The findings from survey for teachers revealed that most teachers were aware of the importance of short stories. In addition, when teachers asked whether short stories were advantageous most of them supported the idea. However, most grade 12 teachers of English at Cristiano Paulo Taimo Secondary School recognize the benefits of short stories in their lessons but most teachers have a little opportunity to use extra materials such as those of short stories other than to stick to the syllabus in the books that they know that will be tested. Few teachers of grade 12 at Cristiano Paulo Taimo Secondary school used their own telling stories when they wanted to motivate their learners to develop English Language Skills.

The findings from observation and survey for students showed that most teachers would rather use more form-focused instruction than communicative activities such as dialogues, role play, simulation, etc. In fact, the teaching of grammar rules was predominant. Teachers did not give time themselves to exploit extra materials. It was also observed in the classroom that teachers used individual work for speaking and listening and this overtly displayed much teacher talking time.

The findings from questionnaire for teachers revealed that most teachers of grade 12 at Cristiano Paulo Taimo Secondary School are more dependent on the students' course book than to bring extra materials in their lessons. Most grade 12 teachers of English did not use short stories in ELT because short stories were not included in the syllabus. On the other hand, most teachers of grade 12 at Cristiano Paulo Taimo secondary school felt restricted by their own limited reading and they were scared to use extra materials or texts designed by unfamiliar authors. In addition, short stories in ELT were not included in the syllabus so, most teachers of grade 12 at Cristiano Paulo Taimo secondary school were scared to deviate what came in the syllabus. The texts for the students to practice reading comprehension were ones related to sports, business, environment, entertainment, technology, diseases, politics, arts and other topics different from short stories. Short stories provide authors the freedom to convey a message or experiment with a theme without the burden of committing to a lengthier, more time-consuming task. By their nature, they are more accessible to more categories of readers, especially students, and provide a more concise format than full-length novels. Since integrating short stories in ELT provide a real model of language use, literary texts offer various benefits in foreign language teaching programs. The researcher expects the research to offer teachers a wealth of different activities for grammar, writing, reading, listening and speaking classes saving them a lot of time.

\section{Conclusion}

The purpose of this study is to find out the role of short stories in learning the English as Foreign Language at Cristiano Paulo Taimo Secondary School. Three specific objectives have been laid out in order to materialize the research. The specific objectives are as they follow: to analyze teachers' perceptions of employing short stories in English Classes at the school aforementioned; to describe the benefits of using short stories in English Language Teaching; and suggest activities to help teachers explore short stories in their English classes. The findings from survey for teachers revealed that most teachers knew the importance of short stories. However, most grade 12 teachers of English at Cristiano Paulo Taimo Secondary School recognize the benefits of short stories in their lessons but most teachers have a little opportunity to use extra materials such as those of short stories other than to stick to the syllabus in the books that they know that will be tested. The findings from observation and survey for students showed that most teachers would rather use more form-focused instruction than communicative activities such as dialogues, role play, simulation, etc. In fact, the teaching of grammar rules was predominant. Most grade 12 teachers of English did not use short stories in ELT because short stories were not included in 
the syllabus. On the other hand, most teachers of grade 12 at Cristiano Paulo Taimo secondary school felt restricted by their own limited reading and they were scared to use extra materials or texts designed by unfamiliar authors. The texts for the students to practice reading comprehension were ones related to sports, business, environment, entertainment, technology, diseases, politics, arts and other topics different from short stories. However, they were some limitations to conduct the present study such as difficult in collecting the questionnaire sheets from teachers and students; some students did not bring the questionnaire sheets back, time pressure; it was not easy to research while teaching. The researcher strongly recommends future researchers to research on the use of other literary genres in EFL at aforementioned school, such as poem and novel and teachers might have similar problem and find adequate techniques and methods to deal with them in classes and find solution to.

\section{References}

[1] ABRAM, M.H.(1970). A Glossary of literary term. New York: Rinehart.

[2] BRUMFIT, C.J.\& Carter, R.A (1986). Literature and Language teaching. Oxford: Oxford University Press.

[3] CARTER, R., \&, Long, M.N.(1991). Teaching Literature. Harlow: Longman.

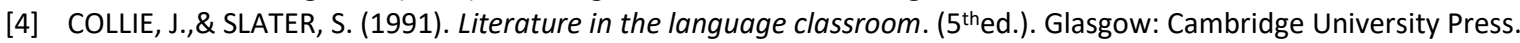

[5] CRESWELL, J. et al (2003). "Advanced Mixed Methods Research Designs." In Tashakkovi,

[6] HILL, J.(1994). Using literature in Language Teaching. London Macmillan.

[7] LAO \& KRASHEN (1989). Literature as content for ESL/EFL.Celce-Murcia (Ed.).Teaching English as a Second or Foreign Language (3rd Edition) (pp.319-332) Boston: Heinle and Heinle.

[8] LAZAR, G. (1993). Literature and language teaching. Cambridge University Press.

[9] LIDDCOAT, A. J. \& Crozet, C (eds.).(2000). Teaching Languages, Teaching Cultures. Melbourne: Language Australia.

[10] LIGHTBOWN, P \& SPADA, N (1993). How Languages are Learned. Oxford: Oxford University Press.

[11] LIGHTBOWN, P \& SPADA, N (1993). How Languages are Learned. Oxford: Oxford University Press.

[12] LITTLEWOOD, W.(2000).Literature in the school foreign - language course. In Brumfit,

[13] MCKAY, S.L.(1986). Literature in the ESL classroom. London: Oxford University Press.

[14] MACIEL, C.M.A.(2007). A Dissertation for Degree of Doctoral in Philosophy: Bantu Oral narratives in the training of EFTeachers in Mozambique. Mozambique. UP. Universidade Pedagógica, Maputo.

[15] MARLEY, A.(1989). Down from the pedestal: literature as a resource. In Brumfit

[16] MILES, M. B \&HUBERMAN, A.M. (1984).Qualitative Data Analysis; A Sourcebook

[17] MPIUKA, T \& MKUTI, L (1987). English for Mozambique. Harare: Zimbabwe.

[18] NKPA, N.(1997). Educational Research. Enugu: $4^{\text {th }}$ Dimension Publishers.

[19] of New Methods. SAGE PUBLICATIONS, Newbury Park London, Delhi.

[20] POVEY, J.F.(1967). Literature in TESOL Programs: the language and the culture. TESOL Quarterly, 1, 40-46.

[21] PRODROMOU, L.(2000). Reason not need: Shakespeare in ELT. IATEFL issues. 156.

[22] Rivers, W.M.(1981). Teaching foreign - language skills. (2nd ed.). Chicago and London: The University of Chicago Press.

[23] SAVVIDOU, C.(2004). Retrieved July, 2010, from http://iteslj.org/Techniques/Savvidou Literature. html.

[24] SELL, R.D.(1995). Why is literature central? Review of English Language Teaching. 5(1), 4-19.

[25] SHANAHAN, D.(1997). Articulating the relationship Between Language, Literature and Culture: Toward a New Agenda for Foreign Language Teaching and Research. The Method Language Journal. 81(2) 164-174.

[26] SMITH, J. (2002). Didactics of Literature. Universidade Pedagógica, Maputo: UP.

[27] STERN, S. (2001). An integrated approach to literature in ESL/EFL. In M. Celce-Murcia (Ed.), Teaching English as a second or foreign language. Heinle \& Heinle. 
Appendix

\section{QUESTIONNAIRE FOR TEACHERS}

This questionnaire aims at finding out if teachers of Cristiano Paulo Secondary School use stories to teach English Language skills in their English classes. Please answer as many questions as you can and your answers will be kept strictly confidential. The results will be used for research purposes only. Please write $\mathbf{Y}$ for yes and $\mathbf{N}$ for NO in the box.

A. Teacher's qualification:

--------------

B. Average student's age

C. Number of students in the classroom

D. Standard

1. Have you ever used short stories in your classes?

2. How often do you use short stories?
a. Always
b. Never
c. Sometimes
d. Rarely

3. What types of literary texts do you use?
a. Folktales
b. Fables
c. Novel
d. Romance
e. Poems
f. Why?

4. Where do you get short stories?
a. School course books
b. Your own story- telling
c. Others, specify
d.

5. Do you think it is advantageous to use short stories to practice any items in English Language?
a. Yes
b. No
c. Why?

6. In what level do you think short stories should be included in language skills classes?
a. Grade 8-9
b. Grade 10
c. Grade 11-12
d. Why?

\section{Thank you very much for your collaboration}


OBSERVATION SHEET

School

Average students' age

Number of students in the class

Teacher's name:

Grade

1. What methods of introducing story the teacher uses
a. Vocabulary
b. Pre-reading questions
c. Guiding questions
d. All techniques

2. Which skill was developed in the class?
a. Listening
b. Reading
c. Speaking
d. Writing
e. Integrated skills

3. What activities did the teacher give students torrelp them practice the language?
a. Pair work
b. Group work
c. Debate
d. Simulation
e. Role play
f. Others

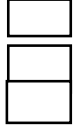

4. What activities used with short stories are suitable for speaking and listening
a) Dictation
b) role play
c) dialogue
d) Individual work
e) All of them

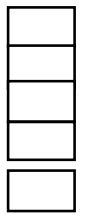




\section{QUESTIONNAIRE FOR STUDENTS}

Questionário de pesquisa sobre o uso de estórias nas aulas de Inglês, caso de estudantes da $12^{\text {a }}$ classe na Escola Secundária Cristiano Paulo Taimo.

Instruções: leia as questões a baixo e marque com um x na alternativa certa e/ou responda as questões onde for necessário, não assine o seu nome:

\section{Género}

Masculino

Idade

\begin{tabular}{|l}
\hline Feminino \\
\hline -15
\end{tabular}

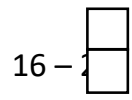

20- 25

2. Que tipo de estórias o teu professor usa nas aulas de Inglês?

f. fábulas

g. contos

h. mitos

i. lendas

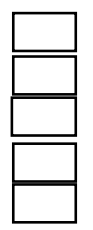

3. Que tipo de actividades o professor usa com estórias?
g. Pair work
h. Group work
i. Debate
j. Simulation
k. Role play
I. Others

4. Quantas vezes o professor utiliza estórias nas suas aulas de Inglês?
f) sempre
g) nunca
h) às vezes
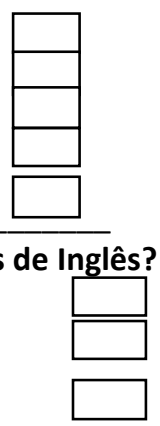


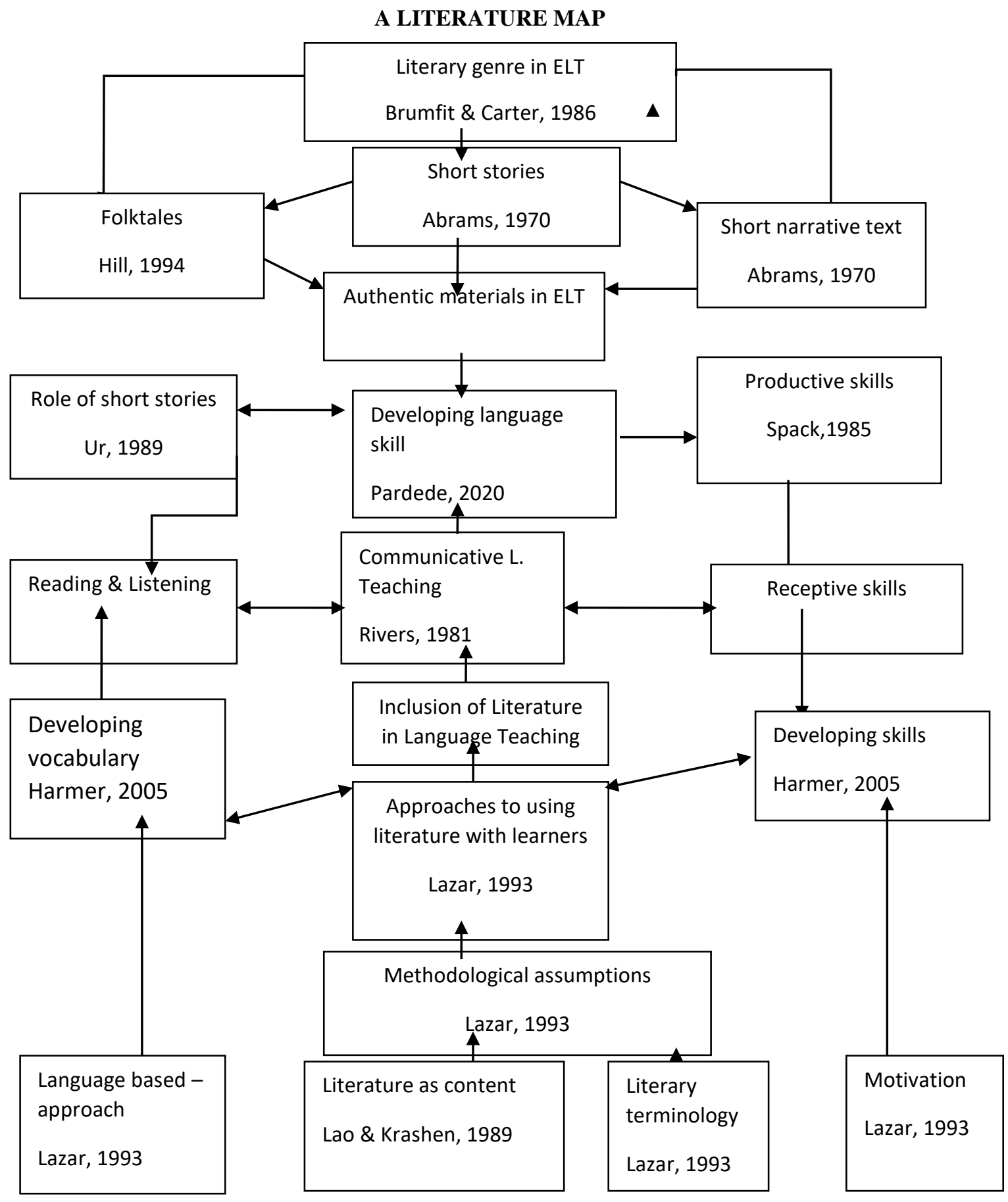

Source: Researcher, 2020 